\title{
The effect of fatty-acid calcium salt and copper supplementation of daily rations on milk yield and composition, lipid metabolism and cholesterol level in cow's milk
}

\author{
F. Brzóska and K. Sala \\ Research Institute of Animal Production, \\ Department of Feed Science and Animal Products \\ Aleksandrowice, 32-083 Balice, Poland
}

(Received 29 December 2000; revised version 6 April 2001; accepted 7 August 2001)

\begin{abstract}
The experiment was conducted on 16 Red-and-White cows in a $2 \times 2$ Latin square design with two levels of CaFA salts (with and without $6 \%$ CaFA salts in DM) and a high or low level of copper (13 vs $61 \mathrm{mg} \mathrm{Cu} / \mathrm{kg} \mathrm{DM}$ ). The cows were fed grass and maize silages and a concentrate in the amount of $0.28 \mathrm{~kg} / \mathrm{kg}$ of milk yield. DM intake of all of the cows averaged $16.8 \pm 0.1 \mathrm{~kg}$, including $10.6 \pm 0.1 \mathrm{~kg}$ of silages at an intake of $6.2 \pm 0.1 \mathrm{~kg} \mathrm{~d}^{-1}$ concentrate. Average FCM was $22.8 \pm 0.5 \mathrm{~kg} / \mathrm{d}^{-1}$, with a content of $4.1 \pm 0.4 \%$ fat, $3.0 \pm 0.3 \%$ protein and $5.4 \pm 0.3 \%$ lactose. A significant negative effect of copper on the fat content of milk was found, whereas the effect of CaFA on daily fat and protein synthesis was positive. The total cholesterol content in milk was $13.6 \pm 0.4 \mathrm{mg} / 100 \mathrm{~g}$ and did not differ significantly for either of the experimental factors. No effect of the experimental factors was found on the $\mathrm{Ca}, \mathrm{P}, \mathrm{Mg}$, and $\mathrm{Zn}$ contents in cow's milk, whereas a significant increase in the $\mathrm{Cu}$ level was observed. Feeding cows CaFA salts significantly lowered the content of saturated fatty acids in milk, i.e. of caprinic $(\mathrm{Cl})$, lauric $(\mathrm{C} 12)$, myristic $(\mathrm{Cl} 4)$ and palmitic $(\mathrm{Cl}$ ) acids, and increased the content of stearic and $\alpha$-linolenic $(\mathrm{C} 18: 3, \mathrm{n}-3)$ acids. The higher copper level significantly elevated the oleic acid (C 18:1) content of milk. CaFA salts led to a highl significant rise in the level of unsaturated fatty acids in milk; the high copper level increased them significantly. The concentration of acids having a cholesterol-lowering effect increased by 40.9 to $46.8 \%$ in response to CaFA salts and by 43.1 to $44.6 \%$ under the influence of copper. No significant differences were found in the glucose, total protein, urea and total cholesterol and HDL levels in the blood plasma of cows. Increased doses of copper lowered the level of LDL cholesterol and increased the plasma activity of aspartate aminotransferase and lactate dehydrogenase. Higher dose of CaFA salts significantly in-
\end{abstract}


creased the plasma activity of alkaline phosphatase and copper level. No effect of the studied factors was found on plasma calcium, phosphorous, magnesium or zinc levels.

KEY WORDS: Ca soap, copper, cholesterol, milk, blood, cow

\section{INTRODUCTION}

Cholesterol in cow's milk is an undesirable factor in terms of human nutrition; its content ranges between $8-13 \mathrm{mg} / 100 \mathrm{~g}$ milk (Brzóska et al., 1999a,b). Dairy products, particularly cheeses that are aged, have a cholesterol content that ranges from 30 to $120 \mathrm{mg} / 100 \mathrm{~g}$ (Buliński and Szydłowska, 1971). Secreting cholesterol into milk by cattle is genetically dependent. The heritability index of milk cholesterol is estimated at about 0.10 and is positively correlated with the contents of fat, protein, and somatic cells (Skrzypek, 1999). The cholesterol content of milk declines slightly in later phases of lactation as well as with the age of cows (Bohac and Rhee, 1988).

In human nutrition, dietary cholesterol is considered to be unnecessary or even harmful. Low-density-lipid cholesterol (LDL) is a cause of vascular arteriosclerosis leading to coronary heart disease. Cholesterol in dairy products accounts for about $50-60 \%$ of the cholesterol consumed by adults. The daily allowance for exogenous cholesterol in human diets has been determined as $300 \mathrm{mg} /$ day, as compared with the approximately $1500 \mathrm{mg} /$ day that are synthesized in the liver (NCEP, 1990; USDA, 1990).

Studies on laboratory animals showed that the copper and zinc levels of diets influence lipid metabolism, including that of cholesterol (Mazur et al., 1993; Rayssiguier et al., 1993). It was shown that mice and rats with highly advanced vascular arteriosclerosis had very low levels of copper in their blood, which suggests that hypocupraemia is a factor in vascular arteriosclerosis. Earlier studies have shown that dietary copper deficiency leads to changes in the activity of liver enzymes, including downregulation of enzymes activity in the cholesterol metabolic pathway (Lei, 1991).

The lipid metabolism of cows depends to a large degree on the level of triglycerides in their diets. Studies were undertaken on the effect of a differentiated level of calcium fatty acid salts (CaFA) and two levels of dietary copper for each level of dietary fat on the cholesterol content of milk and plasma, milk yield, content and daily synthesis of milk components and on the main indicators of protein and fat metabolism in cows.

This study examines the hypothesis that different levels of copper in diets for cows, by acting on liver metabolism, will differentiate the cholesterol level in the blood plasma and milk of cows with the lower copper level raising it, and the higher level, lowering it. 


\section{MATERIAL AND METHODS}

\section{Animals and diets}

The study was carried out on 16 Red-and-White cows in a $2 \times 2$ Latin square design, with two levels of CaFA salts and two levels of copper in the ration. The differentiated doses of copper were administered to cows in a mineral mixture containing anhydrous copper oxide in an amount of 13-14 (low dose) and $60-61 \mathrm{mg} / \mathrm{kg}$ of DM intake (high dose). The daily intake of copper equaled 0.228 and $1.018 \mathrm{~g} / \mathrm{cow} /$ day, respectively. The low dose of copper corresponded approximately to the daily requirement for this element, while the higher dose was substantially above. The zinc content of the diets was maintained on a constant level of $37.50 \mathrm{mg} / \mathrm{kg} \mathrm{DM}$ of the ration in the form of $\mathrm{ZnSO}_{4} \cdot 7 \mathrm{H}_{2} \mathrm{O}$, which is the equivalent of an intake of $1.629 \mathrm{~g} \mathrm{Zn} / \mathrm{cow} /$ day and to the daily requirement of cows for this element (MAFF, 1984; Rogers, 1996).

CaFA salts in the form of the feed fat preparation Erafet were obtained from rape seed oil, fish oil and animal fat in a proportion of 35:5:60. Erafet was added to the concentrate in an amount of $6 \%$ of the daily DM intake, which was the equivalent of about $936 \mathrm{~g}$ of the preparation/cow/day. The experiment comprised 4 periods, each lasting 21 days, including 3 final days during which milk yield was determined and milk samples were taken for analysis. The cows were fed grass and maize silages to appetite and concentrate offered in an amount of $0.28 \mathrm{~kg} / \mathrm{kg}$ milk. The rations were provided twice daily during milking at 7.00 and 16.00 . The concentrate was composed of barley meal, wheat bran and rapeseed oilmeal. The Bovmix mineral mixture (BASF, Kutno, Poland) containing minerals and the appropriate amounts of copper and zinc were added in the mangers to the concentrate in an amount of $80 \mathrm{~g} / \mathrm{cow} /$ day. The mixture contained per kg/g: $\mathrm{P}, 100 ; \mathrm{Ca}, 150$; $\mathrm{Mg}, 40 ; \mathrm{Na}, 70 ; \mathrm{Fe}, 2.5 ; \mathrm{Co}, 0.10 ; \mathrm{Mn}, 3.0 ; \mathrm{Se}, 0.01$; and I, 0.1. Experimental cows between their second and fourth lactations were selected from an experimental herd of 120 cows, taking into account age, number of lactations, calving date, and current yield. They were between the $4^{\text {th }}$ and $16^{\text {th }}$ weeks of lactation. Two weeks before the experiment and during it the cows were fed according to IZ-INRA standards (1993). The cows were housed in a barn on rubber mats, tethered in individual stands. Each of four 21 -day experiments comprised 18 days of an adaptation period and 3 days of the actual experiment during which blood and milk were sampled. During the actual experimental period, silage and concentrate intake was recorded, milk yield was determined, and milk and blood samples were taken for analysis. Cholesterol, fat, protein, lactose, $\mathrm{N}$ fraction, acidity, coagulation time, specific gravity, and mineral components were determined in milk. After completion of cach of these periods, blood was sampled from the jugular vein. Glucose, total protein, urea, triglycerides, total cholesterol, HDL, LDL, alkaline phosphatase 
activity, aspartate and alanine aminotransferase and lactate dehydrogenase activities were assayed in plasma. The dry matter and nutrient contents of feeds were determined.

\section{Chemical analyses}

The milk yield of cows was expressed in standard milk with a $4 \%$ fat content $(\mathrm{FCM}, \mathrm{kg} / \mathrm{d})$ and $3 \%$ protein $(\mathrm{PCM}, \mathrm{kg} / \mathrm{d})$. The nutrient content of feeds was determined by conventional methods (AOAC, 1990). Feed DM was determined at $105^{\circ} \mathrm{C}$, its content in silages was adjusted for volatile substances (Dulphy and Demarquilly, 1981). Total nitrogen and $\mathrm{N}$-fraction in milk were determined by the Kjeldahl method using the Gordon and Kalan (1983) procedure. NDF and ADF contents in feeds were determined by the method of Goering and Van Soest (1970). Fatty acids in milk were assayed as methyl esters using a GLC Varian 3400 gas chromatograph in a DB-FFAP column, according to the method of Atwal et al. (1990). The fat, protein and lactose contents in milk, renneting time, density and acidity were determined in compliance with Polish Standard PN 68/A-86122. The content of minerals in milk and serum was determined by atomic mass spectroscopy using a Philips PU 9000 apparatus after mineralization of samples in nitric acid and hydrogen peroxide in teflon containers using a MEGA-1200 microwave oven. The glucose, crude protein, urea, triglyceride and cholesterol and selected enzyme activities in blood plasma were determined using enzyme-linked tests from Cormay Diagnostyka S.A. (Lublin, Poland). The nutritional value of feeds was expressed according to the INRA-88 system, calculated using Winwar 1.3 software.

The results were subjected to statistical analysis using two-way analysis of variance. The effect of fat, copper, and the interaction of both factors on the analyzed parameters were determined. Averages within rations with and without added fat and using high or low doses of copper were compared by Student's t-test, using the Statgraphics 6.0 software package.

\section{RESULTS AND DISCUSSION}

The composition of the rations is given in Table 1, the chemical composition of feeds in Table 2. Average DM intake per cow was $16.8 \pm 0.1 \mathrm{~kg} /$ day, including $10.6 \pm 0.1 \mathrm{~kg}$ silage and $6.1 \pm 0.1 \mathrm{~kg}$ concentrate (Table 3 ). Supplementing the diets with CaFA salts significantly increased grass and maize silage intake $(\mathrm{P}=0.002)$. The average milk yield for the 84-day experiment was $22.3 \pm 0.5 \mathrm{~kg} /$ day at ayield of $22.8 \pm 0.5 \mathrm{~kg} \mathrm{FCM}$ and $20.3 \pm 0.5 \mathrm{~kg}$ PCM. No significant effects of CaFA salts $(\mathrm{P}=0.260)$ or copper $(\mathrm{P}=0.172)$ on milk yicld were found. The higher copper dose increased the milk yield of animals fed the diets without added fat, while it de- 
TABLE 1

Composition of the rations for dairy cows, in DM \%

\begin{tabular}{lcc}
\hline Item & Without salt of CaFA & With salt of CaFA \\
\hline Maize silage & 30.00 & 30.00 \\
Grass silage & 33.75 & 33.75 \\
Barley ground & 17.40 & 11.60 \\
Wheat bran & 10.40 & 8.40 \\
Rapeseed meal & 7.00 & 9.00 \\
CaSFA (Erafet) & - & 6.00 \\
Limestone & 0.40 & 0.20 \\
Dicalcium phosphate & 0.60 & 0.60 \\
Magnesium oxide & 0.20 & 0.20 \\
NaCl & 0.20 & 0.20 \\
Mineral premix "Bovimix" & 0.05 & 0.05 \\
\hline
\end{tabular}

TABLE 2

Chemical composition and nutritive value of feeds, in DM \%

\begin{tabular}{lcccc}
\hline \multirow{2}{*}{ Nutrients } & Grass silage & \multirow{2}{*}{ Maize silage } & \multicolumn{2}{c}{ Concentrate } \\
\cline { 5 - 5 } & & & without CaFA & with CaFA \\
\hline Dry matter & 24.74 & 27.52 & 87.93 & 87.64 \\
Organic matter & 90.96 & 95.49 & 95.30 & 95.90 \\
Crude protein & 17.10 & 7.60 & 14.15 & 14.75 \\
Ether extract & 4.14 & 3.19 & 6.87 & 10.18 \\
Crude fibre & 27.75 & 27.98 & 8.27 & 7.43 \\
N-free extractives & 41.97 & 56.72 & 66.01 & 63.54 \\
Ash & 9.04 & 4.51 & 4.70 & 4.10 \\
NDF & 66.87 & 63.86 & 35.72 & 37.20 \\
ADF & 32.89 & 31.77 & 9.80 & 10.25 \\
ADL & 5.56 & 5.52 & 4.00 & 4.19 \\
Ca & 7.67 & 4.32 & 9.13 & 9.50 \\
P & 3.35 & 2.12 & 5.27 & 5.41 \\
Cu & 7.56 & 2.28 & 2.91 & 4.40 \\
Nutricnts, kg ${ }^{-1}$ of DM & & & & \\
$\quad$ crude protein, g & 171.0 & 76.0 & 141.5 & 142.5 \\
ME, MJ & 9.75 & 10.23 & 12.34 & 14.20 \\
NEL, MJ & 5.98 & 6.30 & 7.08 & 7.62 \\
UFL & 0.90 & 0.90 & 1.06 & 1.28 \\
PDIN, g & 101.4 & 48 & 103.4 & 105.8 \\
PDIE, g & 78.7 & 62 & 98.7 & 99.2 \\
\hline
\end{tabular}


TABLE 3

Feed intake, milk yield and composition

\begin{tabular}{|c|c|c|c|c|c|c|c|c|}
\hline \multirow{2}{*}{ ltem } & \multicolumn{2}{|c|}{ Without CaFA } & \multicolumn{2}{|c|}{ With CaFA } & \multirow{2}{*}{ SEM } & \multicolumn{3}{|c|}{ P value } \\
\hline & low $\mathrm{Cu}$ & high $\mathrm{Cu}$ & low $\mathrm{Cu}$ & high $\mathrm{Cu}$ & & fat & $\mathrm{Cu}$ & fat $x \mathrm{Cu}$ \\
\hline Feed DM intake, $\mathrm{kg} / \mathrm{d}$ & 16.05 & 16.62 & 17.36 & 17.11 & 0.15 & 0.002 & 0.557 & 0.145 \\
\hline silage & 10.45 & 10.07 & 10.97 & 11.05 & 0.12 & 0.001 & 0.469 & 0.290 \\
\hline maize & 4.90 & 4.72 & 5.14 & 5.18 & 0.06 & 0.001 & 0.486 & 0.305 \\
\hline grass & 5.55 & 5.35 & 5.83 & 5.87 & 0.05 & 0.001 & 0.458 & 0.278 \\
\hline concentrate & 5.52 & 6.48 & 6.31 & 6.11 & 0.14 & 0.422 & 0.146 & 0.029 \\
\hline mineral premix & 0.08 & 0.08 & 0.08 & 0.08 & nd & nd & nd & nd \\
\hline Milk yield, $\mathrm{kg} / \mathrm{d}$ & 20.06 & 23.40 & 23.14 & 22.68 & 0.53 & 0.260 & 0.172 & 0.072 \\
\hline $\mathrm{FCM}, \mathrm{kg} / \mathrm{d}$ & 21.77 & 23.61 & 23.92 & 22.05 & 0.54 & 0.784 & 0.996 & 0.090 \\
\hline $\mathrm{PCM}, \mathrm{kg} / \mathrm{d}$ & 20.34 & 20.76 & 21.24 & 20.53 & 0.51 & 0.288 & 0.550 & 0.199 \\
\hline Fat, $\%$ & 4.38 & 4.02 & 44.14 & 3.90 & 0.44 & 0.028 & 0.000 & 0.478 \\
\hline Protein, \% & 3.09 & 2.91 & 3.05 & 2.98 & 0.33 & 0.768 & 0.049 & 0.357 \\
\hline Lactose, \% & 5.44 & 5.51 & 5.20 & 5.30 & 0.34 & 0.001 & 0.178 & 0.823 \\
\hline \multicolumn{9}{|c|}{ Nutrient synthesis, $g \mathrm{~d}^{1}$} \\
\hline fat & 871 & 944 & 957 & 882 & 22 & 0.784 & 0.985 & 0.090 \\
\hline protein & 621 & 685 & 701 & 677 & 17 & 0.288 & 0.549 & 0.199 \\
\hline Acidity, ${ }^{\circ} \mathrm{SH}$ & 7.17 & 6.94 & 6.74 & 6.78 & 0.06 & 0.158 & 0.893 & 0.124 \\
\hline Renneting time, s & 116 & 163 & 214 & 158 & 17 & 0.043 & 0.512 & 0.052 \\
\hline Density, $g / \mathrm{cm}^{3}$ & 1.030 & 1.030 & 1.029 & 1.030 & 0.0001 & 0.023 & 0.434 & 0.283 \\
\hline
\end{tabular}

$\mathrm{Nd}-$ nol determined

FCM - milk corected for $4 \%$ fat

PCM - milk corected for $3 \%$ protein

creased milk yield in those that received fat-supplemented diets (Table 3 ). The average fat, protein, and lactose contents in milk equaled $4.1 \pm 0.4 \%, 3.01 \pm 0.3 \%$, and $5.3 \pm 0.3 \%$. Supplementing CaFA salts led to a small but significant decrease in the fat content of milk $(\mathrm{P}=0.028)$ and significantly increased the lactose content $(\mathrm{P}=0.001)$, while it had no effect on the protein content. Feeding cows higher copper dose significantly lowered the fat $(\mathrm{P}=0.0004)$ and protein $(\mathrm{P}=0.049)$ levels, whereas it only slightly increased the lactose level in milk. The average daily fat and protein yicld was higher in cows receiving CaFA salts, although the higher level of copper in the rations that were not supplemented with fat increased output, and in the fat-supplemented rations, decreased it. The coagulation time of milk averaged $163 \pm 17 \mathrm{sec}$.

The use of CaFA salts significantly lowered the specific gravity of milk $(P=0.043)$, which averaged $1.0299 \pm 0.0001 \mathrm{~g} / \mathrm{cm}^{3}$ and its acidity $(P=0.023)$, which averaged $6.91 \pm 0.06^{\circ} \mathrm{SH}$.

The results of experiments on the influence of CaFA salts on the milk yield of cows are contradictory, with some showing a positive (Cervantes et al., 1996), and some, a negative (Erickson et al., 1992; Kim et al., 1993; Kowalski, 1997) 
influence. On the basis of studies carried out to date, it can be stated that the milk yield of cows depends on covering of their energy requirements. If the amount of fat in the ration exceeds their requirements, then its effect on milk yield is not manifested, and the excess is stored in adipose tissue through lipogenesis, and usually affects the fatty acid composition of milk. If, however, the ration does not contain enough digestible energy, then the effect of dietary fat on the milk yield of cows is significant, but usually has no effect on milk fatty acid composition.

Increased copper intake did not significantly increase the milk yield of cows $(\mathrm{P}=0.172)$. A higher lactose content in milk was found, however, which can suggest that through its presence in numerous enzymes, copper takes part in the regulation of milk sugar. The least favourable was the influence of copper on the fat and protein levels in milk and the level of daily production of both components of milk. In studies carried out to date, the addition of CaFA salts to rations for cows at a rate of 3-6\% DM increased the fat content of milk (Erickson et al., 1992; Brzóska et al., $1999 \mathrm{a}, \mathrm{b}$ ), accompanied by a negative effect on the protein content of milk (Kim et al., 1991, 1993; Erickson et al., 1992; Kowalski, 1997; Brzóska et al., 1999 a). Nevertheless, a lack of a positive effect of CaFA salts on milk fat was also found (Madison-Anderson et al., 1997). The effect of different dietary copper levels on milk fat and protein contents had not been studied previously. Previous studies on the effect of copper were aimed mainly at determining the optimal content of this element in the ration and on assessing its availability. A tendency towards a lower fat content in the milk of cows fed CaFA salt-supplemented rations was found, which is in disagreement with the results of most earlier studies. The movement of free fatty acids from the plasma to glandular cells is a passive process, and its intensity is proportional to the plasma concentration of these acids (Szostak, 1972). Since no significant effect of CaFA salts on the plasma triglyceride level was found, no effect was found either on the fat level in milk. It was, however, found that the higher copper content of the diet was associated with a significant decline on the milk fat level $(\mathrm{P}=0.0004)$. This indicates that copper participates in the process of synthesizing milk fat, and its excess has an inhibitory effect on it.

The average total cholesterol content in milk was $13.64 \pm 0.40 \mathrm{mg} / 100 \mathrm{ml}$, and no significant effects of feeding cows CaFA salts and adding copper to their rations were found (Table 4). In earlier studies (Brzóska et al., 1999 a,b) the total cholesterol level in the milk of cows in a similar stage of lactation as in this experiment, receiving from 0 to $9 \%$ CaFA salts, was constant and ranged between $10-13 \mathrm{mg} / 100 \mathrm{ml}$. In the present study, we found no significant effect of copper on the plasma or milk cholesterol level. It seems that the metabolism of lipids in the liver in dairy cattle differs from that in monogastric laboratory animals. Feeding cows copper at a level of 13 to $60 \mathrm{mg} / \mathrm{kg}$ DM of the ration neither lowered nor increased the total cholesterol content of milk. 
TABLE 4

Total cholesterol and minerals content in milk

\begin{tabular}{|c|c|c|c|c|c|c|c|c|}
\hline \multirow{2}{*}{ lism } & \multicolumn{2}{|c|}{ Without $\mathrm{CaFA}$} & \multicolumn{2}{|c|}{ With CaFA } & \multirow{2}{*}{ SEM } & \multicolumn{3}{|c|}{ Pvalue } \\
\hline & Iow $\mathrm{Cu}$ & $\overrightarrow{\text { high } \mathrm{Cu}}$ & low $\mathrm{Cu}$ & ligh $\mathrm{Cu}$ & & fal & $\mathrm{Cu}$ & fat $\times \mathrm{Cu}$ \\
\hline $\begin{array}{l}\text { Total cholesterol, } \\
\mathrm{mg} / 100 \mathrm{ml}\end{array}$ & 14.58 & 13.32 & 12.78 & 13.90 & 0.40 & 0.451 & 0.932 & 0.145 \\
\hline $\mathrm{Ca}, \mathrm{mg} / 100 \mathrm{~g}$ & 114.93 & 110.00 & $\{05.8\}$ & 107.40 & 1.66 & 0.079 & 0.612 & 0.324 \\
\hline $\mathrm{P}, \mathrm{mg} / \mathrm{l} 00 \mathrm{~g}$ & 76.83 & 75.52 & 73.73 & 75.19 & 0.93 & 0.362 & 0.969 & 0.461 \\
\hline $\mathrm{Mg}, \mathrm{mg} / 100 \mathrm{~g}$ & 10.32 & 11.00 & 11.04 & 10.81 & 0.12 & 0.338 & 0.261 & 0.837 \\
\hline $\mathrm{Zn}, \mathrm{mg} / 100 \mathrm{~g}$ & 0.468 & 0.458 & 0.448 & 0.464 & 0.010 & 0.612 & 0.790 & 0.324 \\
\hline $\mathrm{Cu}, \mathrm{mg} / 100 \mathrm{~g}$ & 0.025 & 0.033 & 0.028 & 0.032 & 0.001 & 0.618 & 0.011 & 0.272 \\
\hline
\end{tabular}

A significant influence of the higher copper content in rations $(\mathrm{P}=0.011)$ was found on the content of copper in milk. In the rations without CaFA salts, this influence was significant. In relation to calcium, phosphorous, magnesium and zinc, no significant changes in their levels in milk were observed in response to CaFA salt or copper salt supplementation (Table 4).

It was shown that feeding cows higher copper dose (Table 5) significantly decreases the total $\mathrm{N}$ content $(\mathrm{P}=0.034)$ and protein $\mathrm{N}(\mathrm{P}=0.023)$ of milk. The effect of both factors on the $\mathrm{N}$-casein level in milk was insignificant.

TABLE 5

Nitrogen fraction in milk, \%

\begin{tabular}{|c|c|c|c|c|c|c|c|c|}
\hline \multirow{2}{*}{ Item } & \multicolumn{2}{|c|}{ Without CaFA } & \multicolumn{2}{|c|}{ With CaFA } & \multirow{2}{*}{ SEM } & \multicolumn{3}{|c|}{ Pvalue } \\
\hline & low $\mathrm{Cu}$ & high $\mathrm{Cu}$ & low $\mathrm{Cu}$ & high $\mathrm{Cu}$ & & fat & $\mathrm{Cu}$ & fat $x \mathrm{Cu}$ \\
\hline Total N & 0.485 & 0.455 & 0.481 & 0.468 & 0.005 & 0.686 & 0.034 & 0.426 \\
\hline True protein N & 0.457 & 0.425 & 0.450 & 0.436 & 0.005 & 0.861 & 0.023 & 0.362 \\
\hline NPN & 0.030 & 0.030 & 0.031 & 0.031 & 0.0005 & 0.263 & 0.894 & 0.791 \\
\hline Casein N & 0.369 & 0.350 & 0.372 & 0.354 & 0.005 & 0.692 & 0.063 & 0.945 \\
\hline Whey $N$ & 0.100 & 0.091 & 0.097 & 0.098 & 0.001 & 0.554 & 0.132 & 0.082 \\
\hline $\begin{array}{l}\text { True protein } N \text {, } \\
\% \text { of total } N\end{array}$ & 93.74 & 93.38 & 93.50 & 93.28 & 0.12 & 0.475 & 0.230 & 0.779 \\
\hline Casein $N, \%$ of total $N$ & 75.72 & 76.60 & 77.38 & 75.77 & 0.49 & 0.676 & 0.717 & 0.215 \\
\hline
\end{tabular}

The results of this study show that feeding cows diets containing CaFA salts in the amount of $6 \%$ DM made from vegetable oils and fish oil increased the content of unsaturated fatty acids, including MUFA, in milk fat in a highly significant manner ( $\mathrm{P}=0.0001)$, while concomitantly lowering the content of saturated acids, which improves the nutritional value of milk (Table 6). The synthesis of short- 
TABELA 6

Fatty acid composition of the milk fat, $\mathrm{g} / 100 \mathrm{~g}$ of fatty acids

\begin{tabular}{|c|c|c|c|c|c|c|c|c|}
\hline \multirow{2}{*}{ Item } & \multicolumn{2}{|c|}{ Without CaFA } & \multicolumn{2}{|c|}{ With CaFA } & \multirow{2}{*}{ SEM } & \multicolumn{3}{|c|}{$P$ value } \\
\hline & low $\mathrm{Cu}$ & high $\mathrm{Cu}$ & low Cu & high $\mathrm{Cu}$ & & fat & $\mathrm{Cu}$ & tat $x \mathrm{Cu}$ \\
\hline $\mathrm{C}_{\mathrm{x}}$ & 2.5 & 2.6 & 2.4 & 2.4 & 0.12 & 0.58 & 0.73 & 0.87 \\
\hline$C_{10}^{n}$ & 4.6 & 4.7 & 4.0 & 3.6 & 0.10 & 0.00 & 0.32 & 0.17 \\
\hline$C_{12}$ & 4.4 & 4.3 & 3.8 & 3.2 & 0.12 & 0.00 & 0.11 & 0.24 \\
\hline$C_{14}$ & 10.8 & 10.3 & 9.7 & 9.0 & 0.18 & 0.00 & 0.07 & 0.61 \\
\hline$C_{16}$ & 37.1 & 36.7 & 34.1 & 34.0 & 0.50 & 0.00 & 0.77 & 0.88 \\
\hline$C_{16: 1}^{16}$ & 1.4 & 1.5 & 1.1 & 1.3 & 0.04 & 0.00 & 0.05 & 0.58 \\
\hline$C_{18}^{10.2}$ & 12.9 & 12.1 & 15.1 & 14.7 & 0.30 & 0.00 & 0.26 & 0.69 \\
\hline$C_{18: 1}$ & 21.6 & 23.5 & 25.2 & 27.4 & 0.51 & 0.00 & 0.01 & 0.86 \\
\hline $\mathrm{C}_{18: 2}$ & 2.6 & 2.8 & 2.8 & 3.0 & 0.10 & 0.23 & 0.29 & 0.90 \\
\hline$C_{18: 3 n-6}^{10.2}$ & 0.2 & 0.2 & 0.2 & 0.2 & 0.01 & 0.46 & 0.66 & 0.57 \\
\hline$C_{18 \cdot 3 n-3}^{10.5 n-16}$ & 1.0 & 1.0 & 1.2 & 1.2 & 0.04 & 0.04 & 1.00 & 0.69 \\
\hline$C_{20: 4} x^{10 \cdot 3}$ & 0.1 & 0.1 & 0.1 & 0.1 & 0.004 & 0.45 & 0.41 & 0.50 \\
\hline$C_{30: 5}^{20: 4}$ & 0.1 & 0.1 & 0.1 & 0.1 & 0.003 & 0.04 & 1.00 & 0.34 \\
\hline $\mathrm{C}_{22}$ & 0.1 & 0.1 & 0.1 & 0.1 & 0.004 & 0.53 & 0.58 & 0.94 \\
\hline SFA & 72.5 & 70.8 & 69.3 & 66.8 & 0.51 & 0.00 & 0.02 & 0.68 \\
\hline UFA & 27.5 & 29.2 & 30.7 & 33.2 & 0.51 & 0.00 & 0.03 & 0.64 \\
\hline MUFA & 23.6 & 25.0 & 26.3 & 28.6 & 0.43 & 0.00 & 0.02 & 0.51 \\
\hline PUFA & 4.0 & 4.2 & 4.4 & 4.6 & 0.13 & 0.12 & 0.42 & 0.88 \\
\hline PUFA- 6 & 2.9 & 3.1 & 3.2 & 3.4 & 0.10 & 0.24 & 0.31 & 0.92 \\
\hline PUFA-3 & 1.0 & 1.1 & 1.2 & 1.2 & 0.04 & 0.06 & 0.97 & 0.74 \\
\hline DFA & 40.5 & 41.2 & 45.8 & 47.9 & 0.74 & 0.00 & 0.27 & 0.62 \\
\hline OFA & 59.5 & 58.7 & 54.2 & 52.1 & 0.74 & 0.00 & 0.28 & 0.62 \\
\hline PUFA-6/PUFA-3 & 2.9 & 3.0 & 2.6 & 2.9 & 0.01 & 0.00 & 0.04 & 0.54 \\
\hline UFA/SFA & 0.4 & 0.4 & 0.4 & 0.5 & 0.02 & 0.00 & 0.38 & 0.57 \\
\hline DFA/OFA & 0.7 & 0.7 & 0.9 & 0.9 & 0.01 & 0.00 & 0.03 & 0.45 \\
\hline MUFA/SFA & 0.3 & 0.3 & 0.4 & 0.4 & 0.002 & 0.06 & 0.23 & 0.94 \\
\hline PUFA/SFA & 0.1 & 0.1 & 0.1 & 0.1 & 0.09 & 0.23 & 0.26 & 0.75 \\
\hline
\end{tabular}

chain fatty acids like caprinic (C10), lauric (C12), myristic $(\mathrm{C} 14)$, and palmitic (C16; $\mathrm{P}=0.001$ ) acids is lowered, which confirms the results of earlier studies (Brzóska et al., 1999 a,b; LaCount et al., 1994; Madison-Anderson et al., 1997). The synthesis of fatty acids from precursors released in the rumen such as acetic acid and $\beta$-hydroxybutyric acid is energy-consuming, whereas using triglycerides absorbed in the digestive tract does not require an outlay of energy. This suggests that providing cows with 18-carbon and longer chain CaFA salts that are not saturated in the rumen leads to their transport to the mammary gland and use to synthesize the triglycerides of milk fat. The effect of copper in rations for cows on the fatty acid composition of milk was significant, especially at the level of oleic acid (C18:1; $\mathrm{P}=0.0001$ ) and total monounsaturated fatty acids (MUFA; $\mathrm{P}=0.0001$ ). This suggests that the addition of copper may activate enzymes that desaturate fatty acids. 
Analysis of plasma indicators of protein and fat metabolism (Table 7) showed that the level of CaFA salts and copper in the ration had no significant effect on the level of most of the indicators examined. The content of glucose, protein, and urea did not differ significantly among groups of cows. This indicates that the increased level of copper in the diet for cows did not significantly affect the glucose and protein metabolism of these animals. The concentration of triglycerides in blood plasma averaged $7.61 \pm 0.32 \mathrm{mg} / 100 \mathrm{~g}$, that of total cholesterol, $253.51 \pm 6.73 \mathrm{mg} /$ $100 \mathrm{~g}$ and was similar in all groups. The lack of an effect of CaFA salts in diets for cows on the level of plasma triglycerides was shown earlier by Schneider et al. (1988) and by West and Hill (1990), while such an effect was demonstrated by feeding cows tallow or other animal fats (Palmquist and Conrad, 1980; Lough et al., 1988). In studies by Brzóska et al. (1999 a,b) in which cows were fed from 0 to $9 \%$ CaFA salts, the total cholesterol content in the plasma of cows ranged from $193.53 \mathrm{mg} / 100 \mathrm{~g}$ to $288.56 \mathrm{mg} / 100 \mathrm{~g}$, with a high level of high density lipid cholesterol (HDL) being found in the plasma accompanied by a relatively low level of low-density lipid cholesterol (LDL). Maybe this resulted from the diet of the cows being based on structural components such as cellulose, NDF, ADF and starch at a

TABLE 7

Metabolite and mincrals content in blood plasma

\begin{tabular}{|c|c|c|c|c|c|c|c|c|}
\hline \multirow{2}{*}{ Item } & \multicolumn{2}{|c|}{ Without CaFA } & \multicolumn{2}{|c|}{ With CaFA } & \multirow{2}{*}{ SEM } & \multicolumn{3}{|c|}{$P$ value } \\
\hline & low $\mathrm{Cu}$ & high $\mathrm{Cu}$ & low $\mathrm{Cu}$ & high $\mathrm{Cu}$ & & fat & $\mathrm{Cu}$ & fat $x \mathrm{Cu}$ \\
\hline Glucose, $\mathrm{mg} / 100 \mathrm{~g}$ & 58.1 & 58.9 & 57.9 & 58.1 & 5.22 & 0.76 & 0.63 & 0.39 \\
\hline Total protein, $\mathrm{mg} / \mathrm{ml}$ & 11.3 & 11.0 & 10.7 & 10.3 & 0.21 & 0.11 & 0.47 & 0.93 \\
\hline Urca, $\mathrm{mg} / 100 \mathrm{~g}$ & 15.8 & 16.9 & 15.8 & 12.9 & 0.74 & 0.12 & 0.54 & 0.17 \\
\hline $\begin{array}{l}\text { Thriglycerols, } \\
\mathrm{mg} / 100 \mathrm{~g}\end{array}$ & 7.6 & 7.8 & 7.5 & 7.9 & 0.32 & 0.77 & 0.46 & 0.89 \\
\hline $\begin{array}{l}\text { Cholesterol total, } \\
\mathrm{mg} / 100 \mathrm{~g}\end{array}$ & 257.2 & 243.5 & 251.6 & 261.8 & 6.73 & 0.64 & 0.90 & 0.39 \\
\hline $\mathrm{HDL}, \mathrm{mg} / 100 \mathrm{~g}$ & 204.1 & 204.9 & 199.5 & 212.4 & 4.86 & 0.88 & 0.49 & 0.54 \\
\hline $\mathrm{LDL}, \mathrm{mg} / 100 \mathrm{~g}$ & 54.1 & 37.0 & 52.9 & 47.8 & 2.67 & 0.36 & 0.04 & 0.25 \\
\hline AST, U/l & 55.6 & 65.6 & 57.4 & 66.9 & 1.59 & 0.61 & 0.00 & 0.94 \\
\hline $\mathrm{ALT}, \mathrm{U} / \mathrm{l}$ & 19.6 & 20.2 & 20.3 & 18.3 & 0.92 & 0.76 & 0.72 & 0.49 \\
\hline ALP, U/1 & 25.5 & 25.8 & 27.4 & 33.9 & 1.19 & 0.03 & 0.13 & 0.17 \\
\hline LDIt, U/I & 920.2 & 1021.8 & 985.5 & 1027.5 & 16.91 & 0.28 & 0.03 & 0.37 \\
\hline $\mathrm{Ca}, \mathrm{mg} / 100 \mathrm{~g}$ & 11.7 & 11.8 & 11.7 & 10.9 & 0.34 & 0.52 & 0.62 & 0.48 \\
\hline $\mathrm{P}, \mathrm{mg} / 100 \mathrm{~g}$ & 8.6 & 8.2 & 8.9 & 8.2 & 0.39 & 0.73 & 0.84 & 0.77 \\
\hline $\mathrm{Mg}, \mathrm{mg} / 100 \mathrm{~g}$ & 2.6 & 2.7 & 2.6 & 2.6 & 0.09 & 0.87 & 0.71 & 0.66 \\
\hline $\mathrm{Zn}, \mathrm{mg} / 100 \mathrm{~g}$ & 0.6 & 0.6 & 0.5 & 0.6 & 0.02 & 0.74 & 0.40 & 0.89 \\
\hline $\mathrm{Cu}, \mathrm{mg} / 100 \mathrm{~g}$ & 0.2 & 0.2 & 0.1 & 0.1 & 0.01 & 0.45 & 0.92 & 0.94 \\
\hline
\end{tabular}

AST $=$ asparte aminotransferase

ALT = alanine aminotmsferase

ALP = alkaline phosphatase

$\mathrm{LDH}=$ lactate dehydrogenase 
relatively low amount of fat in the ration. In the present study, no significant influence was found either in the plasma HDL cholesterol level, which does not significantly differentiate this indicator for the higher and lower copper levels. A significant effect of higher copper doses was found, however, on lowering the content of LDL cholesterol in the plasma of cows $(\mathrm{P}=0.036)$. The results of this study indicate that the level of copper in the diets of ruminants does not significantly modify the level of total plasma or milk cholesterol. On the basis of studies carried out to date on laboratory animals, it was accepted that a low dietary copper level induces hypercholesterolaemia and vascular disorders in animals (Mazur et al., 1993; Rayssiguier et al., 1993). A copper deficit induces hypercholesterolaemia in rats (Klevay, 1973), and feeding chickens and turkeys diets with low levels of copper led to lowering plasma and muscle cholesterol levels (Pesti et al., 1994; Bakalli et al., 1995; Pesti and Bakalli et al., 1996). It is suggested that hypercholesterolaemia in animals with copper deficits may be the result of increased hepatic cholesterol synthesis (Al-Othman et al., 1992). The results of our experiment showed that very different levels of copper in rations significantly lowered plasma LDL levels, but did not affect total cholesterol in milk. A lower level of copper in the diets was not attainable because of the presence of copper in the basic feeds, mainly silages and organic components of feed mixtures. The mechanism of transferring cholesterol from plasma to milk in cows is still not understood, nor are the factors affecting it known. Given that the plasma level of total cholesterol is about $250 \mathrm{mg} / 100 \mathrm{~g}$ of blood plasma, lowering it to $11-13 \mathrm{mg} / 100 \mathrm{~g}$ milk is a very large difference. This suggests that the epithelial cells of mammary gland follicles contain lipoprotein receptors that limit their level in milk. If this is true, then to explain the lowering of the cholesterol level in milk it would be necessary to know the factors

affecting the activity of these receptors. Moreover, a rise in the activity of plasma aspartate aminotransferase and lactate dehydrogenase was observed, which would indicate that copper takes part in the activation of both enzymes. The average activity of both enzymes in cow serum corresponded with the figures obtained in earlier experiments on Ayrshire bull calves by Huhtanen and Poutiainen (1985). Higher levels of CaFA salts significantly increased the activity of alkaline phosphatase in the blood of cows.

\section{CONCLUSIONS}

In summary, it can be said that a differentiated level of copper in rations for dairy cows, ranging from $131061 \mathrm{mg} / \mathrm{kg} \mathrm{DM}$, does not affect milk production or the more important parameters of milk, but does lower the fat and protein, including cascin and whey protein, levels in milk. It also does not lead to significant changes in the total cholesterol level in milk. This means that highly varied levels 
of copper in diets for cows do not significantly modify the process of endogenous cholesterol synthesis in the liver. Increased copper intake in rations significantly increases the content of monounsaturated fatty acids (MUFA), mainly oleic acid (C18:1) and total unsaturated fatty acids (UFA) in milk. A high level of copper in diets for cows significantly lowers the plasma LDL cholesterol level, which does not, however, affect the total cholesterol level of milk. No significant effect of this factor on the level of the main mineral components of milk and plasma was observed, while the copper level in milk was found to rise.

Feeding cows fatty acid calcium salts (CaFA) in an amount of $6 \% \mathrm{DM}$ of the ration increases the milk yield of cows, lowers the fat and lactose contents of milk. It does not, however, affect the cholesterol and mineral levels of milk. Consuming fat in the form of CaFA salts significantly increases the content of monounsaturated fatty acids (MUFA) and $\alpha$-linolenic acid (C18:3, n-3) in milk fat, which improves the nutritional quality of milk. The use of different levels of copper and CaFA salts in feeding cows does not significantly affect the glucose, total protein, urea, or total cholesterol and HDL levels in the plasma of cows.

\section{ACKNOWLEDGEMENTS}

Central Laboratory of the Institute are acknowledgemented for chemical analysis of feeds, milk, blood and statistical calculations.

\section{REFERENCES}

Al-Othman A.A., Rosenstein F., Lei K.Y., 1992. Copper deficiency alters plasma pool size, percent composition and concentration of lipoprotein components in rats. J. Nutr. 122, 1199-1204

AOAC, 1990. Official Methods of Analysis. Association of Official Analytical Chemists. I5th Edition. Arlington, VA

Atwal A.S., Hidiroglou M., Kramer J.K.G., Binns M.R., 1990. Manipulation of the fatty acids composition of milk by feeding protected canola seeds. J. Dairy Sci. 75, 1090-1096

Bakalli R.I., Pesti G.M., Ragland W.L., Konjufca V., 1995. Dietary copper in excess of nutritional requirements reduces plasma and breast muscle cholesterol of chickens. Poultry Sci. 74, 360-365

Buliński R., Szydłowska E., 1971. Estimation of free cholesterol in food of animal origin (in Polish). Bromat. Chem. Toksykol, IV (1), 59-65

Brzóska F., Gąsior R., Sala K., Zyzak W., 1999a. Effect of linseed oil fatty acid calcium salts and vitamin $E$ on milk yicld and composition. J. Anim. Fecd Sci. 8, 367-378

Brzóska F., Gąsior R., Sala K., Wiewióra W., 1999b. Effect of calcium salts of fatty acids from animal fat, rape oil, linseed oil and fish oil on the yield and composition of cow's milk. Ann. Anim. Sci. 26 (2), 105-117

Cervantes A., Smith T.R., Young J.W., 1996. Effects of nicotynamide on milk composition and production of dairy cows fed supplemental fat. J. Dairy Sci. 79, 105-113 
Dulphy J.P., Demarquilly C., 1981. Problems particuliers aux ensilages, prevision de la valuer nutritive des aliments des ruminants. INRA Publ., pp. 81-104

Erickson P.S., Murphy M.R., Clark J.11., 1992. Supplementation of dairy cows diets with calcium salts of long chain fatty acids and nicotinic acid in carly lactation. J. Dairy Sci. 75, 1078-1089

Goering H.R., van Socst P.J., 1970. Forage Fiber Analysis. Agriculture Handbook, No. 379, USDA, Washington, DC

Gordon W.G., Kalan E.B., 1983. Proteins in milk. In: Fundamentals of Dairy Chemistry. $2^{\text {nd }}$ Edition. B.H.Webb, A.H. Johnson, J.A. Alford (Editors). AVl Publ. Co., Inc., West Port, CT, pp. 78

Huhtanen P., Poutiainen E., 1985. Effect of full-fat rapesecd on digestibility and rumen fermentation in cattle. J. Agr. Sci. Finland 57, 67-73

IZ, 1993. Nutrient Requirements of Cattle, Sheep and Goats (in Polish). Editor: Research Institute of Animal Production, Kraków (Poland) and Omnitech Press, Warszawa (Poland)

Kim Y.K., Schinoethe D.J., Caspar D.P., Ludens F.C., 1991. Lactational response of dairy cows to increased dietary crude protein with added fat. J. Dairy Sci. 74, 3891-3899

Kim Y.K., Schinoethe D.J, Caspar D.P., Ludens F.C., 1993. Supplemental dietary fat from extruded soybeans and calcium soaps of fatty acids for lactating dairy cows. J. Dairy Sci. 76, 197-204

Klevay L.M., 1973. Hypercholesterolemia in rats produced by an increase in the ratio of zinc to copper ingested. Amer. J. Clin. Nutr. 26, 1060-1068

Kowalski M.Z., 1997. Calcium soaps of rape seed oil fatty acids in cattle nutrition. Zesz. Nauk. AR Kraków, Thesis, No. 228

LaCount D.W., Drackley J.K., Laesch S.O., Clark J.H., 1994. Secretion of oleic acid in milk fat in response to abomasal infusions of canola of high oleic sunflower fatty acids. J. Dairy Sci. 77, 1372-1385

Lough D.S., Muller L.D., Kensinger R.S., Sweeney T.F., Griel L.C. Jr., 1988. Effect of added dietary fat and bovine somatotropin on the performance and metabolism of lactating dairy cows. J. Dairy Sci. 71, 1161-1169

Madison-Anderson R.J., Schingoethe D.J., Brouk M.J., Baer R.J., Lenrsch M.R., 1997. Response of lactating cows to supplemental unsaturated fat and niacin. J. Dairy Sci. 80, 1329-1338

MAFF, DAFS, DANI, UKASTA, BVA Working Party Report, 1984. Mineral, trace element and vitamin allowances for ruminant livestock. In: W. Haresign, J.A. Cole (Editors). Recent Advances in Animal Nutrition. Butterworths, pp. 113-143

Mazur A., Nassir F., Gueux E., Rayssiguier Y., 1993. Plasma lipoprotcins and apolipoproteins in copper deficient rats: studies on apolipoprotein synthesis and gene expression. In: A. Anke, D. Meissner, C.F. Mills (Editors). Trace Element in Man and Animals - TEMA 8, pp. 525-529

National Cholesterol Education Program, 1990. Report of the Expert Panel on Population Strategies for Blood Cholesterol Reduction. USD Health Human Service. National Institute of Health, No. 90-3046, Washington, DC

Palmquist D.L., Conrad H.R., 1980. High fat rations for dairy cows. Tallow and hydrolyzed blended fat at two intakes. J. Dairy Sci. 63, 391-395

Pesti G.M., Bakalli R.I., 1996. Studies on the feeding of cupric sulfate pentahydrate and cupric citrate to broiler chickens. Poultry Sci. 75, 1086-1091

Pesti G.M., Bakalli R.I., Ragland W.L., 1994. Reduction of turkey plasma cholesterol by dietary copper supplementation. Reprod. Nutr. Develop. 34, 624-625

Polish Standard (PN 68/A-86122). Milk. Investigation Mcthods (in Polish)

Rayssiguier Y., Gueux E., Motta C., Mazur A., 1993. Effect of copper deficiency in rats on lipoprotein and tissue peroxidation. In: A. Ankc, D. Meissner, C.F. Mills (Editors). Trace Element in Man and Animals - TEMA 8, pp. 530-534 
Rogers P.A.M., 1996. Effective oral trace-element supplements for cattle and sheep. Teagasc, Grange Research Centre, Dunsany, Co. Meath, May 5, pp. 1-14

Schneider P., Sklan D., Chalupa W., Kronfeld D.S., 1988. Feeding calcium salts of fatty acids to lactating cows. J. Dairy Sci. 71, 2143-2150

Szostak W.B., 1972. Disturbances in lipid metabolism (in Polish). In:. W. Hartwig (Editor). Clinical Endocrinology. PZWL, Warszawa (Poland), pp. 1061-1108

USDA, Department of Health and Human Services, 1990. Nutrition and your Health: Dietary Guidelines for Americans. 3rd Edition. Washington, DC

West J.W., Hill G.M., 1990. Effect of a protected fat product on productivity of lactating Holstein and Jersey cows. J. Dairy Sci. 73, 3200-3207

\section{STRESZCZENIE}

\section{Wplyw soli wapniowych kwasów tluszczowych i miedzi w dawce pokarmowej na wydajność i skład mleka oraz przemianę tluszczową u krów}

Doświadczenie przeprowadzono na 16 krowach rasy czb, w układzie kwadratu łacińskiego $2 \times 2$, stosując w dawkach dwa poziomy soli CaFA (bez i z dodatkiem $6 \%$ soli CaKT w s.m.) oraz dwa poziomy miedzi (13 vs $61 \mathrm{mg} \mathrm{Cu} / \mathrm{kg} \mathrm{s.m.).} \mathrm{Krowy} \mathrm{żywiono} \mathrm{kiszonką} \mathrm{z} \mathrm{traw} \mathrm{i} \mathrm{z} \mathrm{kukurydzy} \mathrm{do} \mathrm{woli}$ oraz mieszanką treściwą podawaną w ilości $0,28 \mathrm{~kg} / \mathrm{kg}$ mleka. Pobranie s.m. przez wszystkie krowy wynosiło średnio $16,8 \pm 0,1 \mathrm{~kg}$, w tym $10,6 \pm 0,1 \mathrm{~kg}$ kiszonki i $6,2 \pm 0,1 \mathrm{~kg} / \mathrm{d}^{-1}$ mieszanki treściwej. Średnia wydajność mleka FCM wynosiła $22,8 \pm 0,5 \mathrm{~kg} / \mathrm{d}^{-1}$, przy zawartości tłuszczu $4,1 \pm 0,4 \%$, białka $3,0 \pm 0,3 \%$ i laktozy $5,4 \pm 0,3 \%$. Stwierdzono statystycznie istotny, ujemny wpłw miedzi na zawartość tłuszczu w mleku, przy dodatnim wpływie soli CaKT na wielkość dobowej syntezy tłuszczu i białka. Zawartość cholesterolu całkowitego w mleku wynosiła $13,6 \pm 0,4 \mathrm{mg} / 100 \mathrm{~g}$ i nie różniła się istotnie w zależności od badanego czynnika. Nie stwierdzono także ich wpływu na zawartość $\mathrm{Ca}, \mathrm{P}, \mathrm{Mg}$ i Zn w mleku, przy istotnym wzroście poziomu $\mathrm{Cu}$. Podawanie krowom soli CaKT istotnie obniżyło w mleku zawartość kwasów nasyconych, kaprynowego (C10), laurynowego (C12), mirystynowego (C14) i palmitynowego (C16), a zwiększyło zawartość kwasu stearynowego $(\mathrm{C} 18) \mathrm{i} \alpha$-linolenowego $(\mathrm{C} 18: 3$, $\mathrm{n}-3)$. Wyższy poziom miedzi w dawce wpłynął na istotne zwiększenie zawartości kwasu oleinowego (C 18:1) w mleku. Podawanie krowom soli CaKT wysoce istotnie, a większej ilości miedzi istotnie zwiększyło poziom kwasów nienasyconych w mleku. Dodatek soli CaKT spowodował zwiększenie od $40,9 \%$ do $46,8 \%$ poziomu kwasów o działaniu hipocholesterolemicznym, a miedzi od $43,1 \%$ do $44,6 \%$.

Nie stwierdzono istotnych różnic w zawartości glukozy, białka całkowitego, mocznika oraz cholesterolu całkowitego i HDL w osoczu krwi. Zwiększone dawki miedzi istotnie obniżyły poziom cholesterolu niskocząsteczkowego, a zwiększyły aktywność aminotransferazy asparaginowej i dehydrogenazy mleczanowej w osoczu krwi. Wyższe dawki soli CaKT istotnie zwiększyły aktywność fosfatazy alkalicznej i miedzi w osoczu krwi. Nie stwierdzono wpływu badanych czynników na poziom wapnia, fosforu, magnezu i cynku w osoczu krwi. 